\title{
PORTUGUESE TILES: A PROJECT-BASED LEARNING EXPERIENCE
}

\section{AZULEJOS PORTUGUESES: UMA EXPERIÊNCIA DE APRENDIZAGEM BASEADA EM PROJETO}

\author{
Renato Alvim ${ }^{1}$ \\ Silvia Ramos Sollai ${ }^{2}$
}

\begin{abstract}
This mixed-methods study examines the interrelated nature of a target language and culture acquisition and project-based learning (PBL) at a U.S. West Coast university. From researching to creating their own Portuguese-style tiles as the public cultural products of practices and perspectives at a Portuguese World Language class, instruction and learning are triangulated under the theoretical tenets of PBL and World Languages (WL) approaches. PBL is grounded in crosscutting design principles of real-world utility (CONDLIFFE et. al, 2017). Similarly, WL reflects the increasing importance of the five Cs in learner-centered and proficiency-oriented instruction for a globalized world (KATRADIS, FOX \& TIAN, 2017). Results show that while experiential learning has become an increasingly central component of capacity building, the ongoing debate regarding how to implement intercultural communication and global competence skills continues (ACTFL, 2012).
\end{abstract}

\section{KEYWORDS}

Project-Based Learning (PBL). Portuguese World Language (PWL). The five Cs. Learner-centered and proficiency-oriented instruction. Cultural products, practices, and perspectives.

\section{RESUMO}

Este estudo de métodos mistos examina a natureza entrelaçada de aquisição de idiomas e culturas-alvo e Aprendizagem Baseada em Projetos (ABP) numa universidade da costa oeste dos EUA. Desde a pesquisa à criação de seus próprios azulejos no estilo português como produtos culturais públicos de práticas e perspectivas numa aula de Português Lingua Mundial (PLM), a instrução e o aprendizado são triangulados sob os princípios teóricos da ABP e da Língua Mundial (LM). ABP está fundamentada nos princípios de projeto com utilidade no mundo real (CONDLIFFE et. al, 2017). Da mesma forma, LM reflete a crescente importância dos cinco Cs no ensino centrado no aluno e orientado pela proficiência para um mundo globalizado (KATRADIS, FOX \& TIAN, 2017). Os resultados mostram que embora a aprendizagem experimental se torne cada vez mais central na capacitação, o debate continua sobre como implementar a comunicação intercultural e as habilidades de competência global (ACTFL, 2012).

\section{Palavras-Chave}

Aprendizagem Baseada em Projetos (ABP). Lingua Mundial Portuguesa (PLM). Os cinco Cs. Instrução centrada no aluno e orientada pela proficiência. Produtos, práticas e perspectivas culturais.

\footnotetext{
1 Ph.D. in Lusophone Cultures (Second Area in Latin American Studies) from Indiana University, Bloomington, USA, Assistant Professor at California State University, Stanislaus, USA.

2 Ph.D. in Curriculum and Instruction (Second Area in Foreign and Second Language Teacher Education Program) from Florida State University, USA
} 


\section{LEARNING BY DOING}

Scholars have always claimed that Project Based Learning (PBL) revitalizes class environment due to its application in real-world scenarios, its use of challenges to increase knowledge and skills during designated project periods (BRANDL, 2002; CONDLIFFE et. al, 2017; OMAGGIO-HADLEY \& TERRY, 2001). The goal of using complex questions or problems is to develop and enhance student learning by encouraging critical thinking, problem solving, teamwork, and self-management. Leiva Matus (2018, p.18) exemplifies the intentional purpose with an English as a Foreign Language book project to tenth graders after participation and independence were detected by a needs analysis, "the need was born from the fact that they had a hard time reading three literary books from different subjects at the same time, probably because they did not know what to pay attention to in a book".

With respect to purposefulness, Dooly \& Randall (2016) state that the proposed question of a project drives students to make their own decisions, perform their own research, while they review their own and their fellow students' processes. Thus, in addition to finding resources, developing project timelines, and learning to overcome obstacles, students have the opportunity to publicly display their work. We argue that displaying their cultural products in public gives students the chance to grow their presentational communication while explaining their project's outcome.

PBL is an integral key for increasing learning success and long-term growth. After all, the combination of collaboration, reflection, and individual decision-making gives the students an applicable scenario that they will face as they mature. Moreover, the authenticity of PBL allows voicing of personal interests, concerns, or issues that are significant parts of students' lives. Instead of a pre-determined project or assignment, all involved can witness the issues or concerns in their community, discover one that they find particularly interesting, and brainstorm ways to address or solve the problem (TROYAN, 2012). Allowing students to have this control, PBL can develop deeper learning proficiencies necessary for career building (FRAGOULIS \& TSIPLAKIDES, 2009). Moreover, one could say that Portuguese World Language PBL becomes much more engaging through the active participation in projects that focus on pluricentric heritage learning. The glazed ceramic tiles are deeply embedded in the Portuguese history and culture. Furthermore, PBL cultural products that derived from practice and perspective provide content and skills that can actively apply in intercultural communication and global competence that future demands.

Fredricka L. Stoller (2002) lays out a rationale in which inquiry promotes meaningful engagement for participatory learning. Endorsed by Grabe \& Stoller (2018), learners are to develop deep investigative skills so as to respond to an authentic challenging task. A parallel can be drawn with pragmatism, as Frey (1986, p.31) coined the term with the philosophical movement that promotes the practical application of knowledge. Dewey (1935) and Kilpatrick (1937) were some of U.S. major advocates, to name a few. Currently, Kingston (2018), Mergendoller (2016), and Saavedra et al. (2016) relate experiential learning to foreign language acquisition. Likewise, ${ }^{\circ}$ Buck Institute for Education proposes seven steps to the Gold Standard Project Based Learning and Teaching:

\section{The Gold Standard for PBL Works practices}

Teaching: design and plan, Standards alignment, culture building, activities management, scaffolding, assessment, and engagement. 
Learning: challenge, sustained inquiry, authenticity, voice, reflection, critique and revision, and public product.

CBuck Institute for Education Licensed under Creative Commons BY-NC-ND 4.0

Figure 1: The High Quality for PBL Works Framework by ${ }^{\circ}$ Buck Institute for Education. Image used for research purpose with appropriate educational objectives in nature, amount, and effect. No copyright required under the guidelines of fair use.

From the list above, it can be inferred that both acquisition and instruction are measurable in projects. When it comes to teaching, ${ }^{\circ}$ Buck Institute for Education believes a transition to PBL is smoother when the design incorporates the learner's context and voice. Moreover, aligning projects to the local/federal standards calibrates practice. When the teachers promote implicit and explicit motivation for their learners to exercise independence and meet deadlines, they are building culture and developing management skills, respectively. Optimized instruction responds for scaffolding. The teachers should remember to realign goals and learn along.

Under the learning gold practices, ${ }^{\circ}$ Buck Institute for Education suggests a meaningful age-appropriate question challenges the problem, rigorous research engagement responds for inquiry sustainability. Needless to say, realistic tasks, tools, quality standards, impact, concerns, and learner's interest guarantee PBL authenticity. Voice is PBL essence to enhance the learner's decision-making process so as to reflect on strategies for the obstacles that may arise. ${ }^{\circ}$ Buck Institute for Education reinforces feedback as the critique and revision. Ultimately, the product is maturely developed for public display beyond the rehearsed and predictable classroom setting.

Considering that pragmatic learning has real world relevance, the curriculum that employs the appropriate level of complexity and the natural integration of pluricentric Portuguese authentic material favors utility. However, the World Readiness Standards for Learning Languages are subdivided in Communication, Cultures, Comparison, Connections, and Communities (5Cs) by the American Council on the Teaching of Foreign Languages (ACTFL, 2015) so the learner perceives the target culture gradually as products with books, food, and songs; then practices with patterns of behavior (such as gestures), and finally, perspectives with beliefs, attitudes, and values (LUNDGAARD \& SAUER, 2018). Importantly, YOUNG (1999) theorizes that intercultural communication, as appreciation and projection in other cultures per se, is ultimately reached through perspectives.

A large number of existing studies looked into the various modalities of Portuguese instruction in the U.S. For instance, while Brito (2015) researches gender in interlanguage, Osborne (2017) looks into film and content alignment. Nonetheless, no systematic narrative has cross-examined participatory learning with practice, perspective, and product. Given this circumstance, the purpose of this study is to integrate information from qualitative report (focus groups, interviews interpretation) with quantitative data (data collection, questionnaire analysis, survey)_to describe the project-based learning experience in which Portuguese tiles become the public cultural products, a PBL jargon that reinforces presentational skills.

Besides being considered a less commonly taught language, Portuguese was declared a critical language by the Departments of Defense, and Homeland Security, as well as by some other federal stances in the United States of America. In other words, because there are fewer than desired U.S. citizens holding strategic positions in governmental agencies, such as the Federal Bureau 
of Investigation (FBI), with a near-native or a native-like Portuguese proficiency, federal and state-level funds were and are being allocated under the National Security Language Initiatives (NSLI) in order to guarantee the sustainability of K-16 Portuguese as a Foreign Language classes, that is, from kindergarten all the way to higher education 5000 levels.

\section{BACKGROUND AND HISTORICAL INFLUENCE}

Portuguese World Language PBL is not without its challenge. Even though the many benefits of participatory projects have been long suggested in studies, issues with curriculum budget and schedule deadlines are still faced. Moreover, even though this case study participants and subject school are located in a U.S. West coast state where Portuguese influence is significantly relevant, enrollments for Portuguese classes continue to fluctuate. Almeida (2019) explains that the public records from the Regional Oral History Office show that the Portuguese immigrants and their descendants arrived in the San Francisco Bay Area and beyond aboard American whaling ships - upon which many served - long before the Gold Rush (UNIVERSITY OF CALIFORNIA BERKELEY, 2019). Although settling in urban centers too, Portuguese have traditionally preferred rural areas, where they have been especially active in the state's dairy industry. Immigration from mainland Portugal, as well as from the islands of Azores and Madeira peaked in alternated times in history. This is a geographical area that is significantly interested and shaped by Portuguese pluricentric products (bakeries, businesses) demonstrated in daily practices (heritage language clubs, street names) through rooted perspectives (cultural maintenance).

All of that said, experiential learning by doing dates back from the first educators and schools of thought. So do the Portuguese tiles, introduced in the 13th century when the Moors invaded the land and rooted their influence into Spain and Portugal. The word azulejo stems from Arabic roots, meaning small polished stone (FRAGA, 2018). Originally, they were fairly simple structures cut into geometric shapes in neutral tones. Coentro (2010) reports that after their introduction by King Manuel I, simple geometric shapes were replaced by more ornate decoration. Typically, the Portuguese would use the tiles to talk about their history, religion, etc.

\section{World Readiness and Global Competence}

Critical reflective thinking is essential in both instruction and learning when developing capacity building in a globalized world. It helps teachers and learners ground and analyze their decisions personally and professionally. For world readiness, the American Council on the Teaching of Foreign Languages (ACTFL, 2012) proposes the implementation of communication, cultures, comparison, connections, and communities, namely the five Cs, as areas used to trace down concrete (products) and abstract (practices and perspectives) goals in preparing WL classes. Thomé-Williams (2016) neatly lists the highlights of each goal area as:

\begin{tabular}{|c|l|c|}
\hline THE FIVE Cs & \multicolumn{1}{c|}{ GOAL AREAS } \\
\hline \multirow{3}{*}{ Communication } & $\bullet$ Engage in conversations in a language other than English \\
& $\bullet$ Exchange opinions in this language \\
& - Interpret written and spoken discourse \\
& - Present information for listeners or readers on different topics \\
\hline
\end{tabular}




\begin{tabular}{|c|c|}
\hline Cultures & $\begin{array}{l}\text { - Demonstrate an understanding of practices, products, and } \\
\text { perspectives of the culture studied }\end{array}$ \\
\hline Connections & $\begin{array}{l}\text { - Turn the study of a foreign language and culture into a bridge to the } \\
\text { content of other disciplines } \\
\text { - Recognize different viewpoints and perspectives in order to further } \\
\text { knowledge in various fields }\end{array}$ \\
\hline Communities & $\begin{array}{l}\text { - Participate in multilingual communities at home and around } \\
\text { the world to enrich the language learning experience and build } \\
\text { relationships }\end{array}$ \\
\hline Comparisons & $\begin{array}{l}\text { - Compare various languages and cultures in many layers } \\
\text { - Enhance the development of insights into the new language and } \\
\text { culture }\end{array}$ \\
\hline
\end{tabular}

Figure 2: The five Cs goal areas by ${ }^{\circ}$ ACTFL (2012). Adapted from Thomé-Williams (2016). Image used for research purpose with appropriate educational objectives in nature, amount, and effect. No copyright required under the guidelines of fair use.

Translating assists comprehension. In a foreign language class, the learner may be able to comprehend a passage in the target language with the aide of translation. The learner; however, may not be able to interpret the implicit message, or to catch the writer's "intention". So, it is somewhat coherent to state that comprehension differs from interpretation. Additionally, in-depth research has concluded that communication happens not only during speaking but also during interpretation because the learner interacts with the text when he or she understands from within a cultural mindset, or reads between lines (CARLA, 2017; SHRUM \& GLISAN, 2010). It goes without saying that text is every communication process that is endowed with meaning (GUIMARÃES, 2009).

After weighing both sides of the argument - that communication entails interpretation, and that text can be verbal, visual, or written - one concludes there can be a two-way or a one-way communication: a dialogue or a presentation to an audience, respectively. Hence, ACTFL (2012) proposes three modes of communication for the World Language (WL) approach: interpretive, interpersonal, and presentational (KISSAU \& ADAMS, 2016). The interpretive communication focuses on what learners understand, interpret, and analyze from what is heard, read, or viewed on a variety of topics; the interpersonal communication is the learners' interaction and negotiation of meaning in spoken, signed, or written conversations to share information, reactions, feelings, and opinions. Presentational communication have learners present information, concepts, and ideas to inform, explain, persuade, and narrate on a variety of topics using appropriate media and adapting to various audiences of listeners, readers, or viewers (DUNCAN \& MET, 2010).

The well-known progressive state of California, where this study was conducted, has just revisited the National World-Readiness Standards for Learning Languages to propose the integration the five Cs into three curricular strands: communication, cultures, connections. Now, California Language Teachers' Association (CLTA, 2019) incorporates communities and comparisons into communication, and comparison into cultures. The justification for such bold state-level action is that global competence is the disposition of seeing oneself and acting on issues of global signifi- 
cance beyond one's own language(s) and culture(s). California's four domains of global competence are: 1) Investigate the world beyond one's immediate environment; 2) Recognize perspectives, others' and own; 3) Communicate ideas effectively with diverse audiences; 4) Take actions to improve conditions. It takes a village to foster awareness and curiosity about how the world works: educators, students, parents/guardians, and community partners can be informed by these interdisciplinary domains as indicators of lifelong learning skills.

\section{Participatory design}

This mixed-methods study converges the interpretation from the students' qualitative feedback (focus group interviews, open-ended written report) with the information from quantitative data (percentage analysis, survey) to describe and analyze project-based learning experience with tiles as cultural products.

As a way to both enhance Portuguese communication skills and awareness on the cultural aspects of the Lusophone world, this project-based chapter on their academic path was set as a sequence of activities that culminated in the presentation of their final product: Portuguese-like painted tiles.

The first step was to brainstorm the participants' initial ideas about the topic: what the tiles represent, their origin, historical relevance, various uses, styles, and designs. Students would also establish comparisons with the tiles of nowadays. It was important also to highlight that even though it is a tradition in Portugal since the $17^{\text {th }}$ century, it is not a reference to old or dated objects. It is still present nowadays with many modern aspects and contemporary styles and tendencies. Subsequently, an authentic reading about the relevance, history, and most significant samples of tiles around Portugal was assigned: many in convents, monasteries, public buildings, churches, schools, and palaces. In the sequence, a live presentation was broadcasted on camera from a ceramic studio in Brazil. The next step was the preparation of drawings/drafts of motifs of tiles to be produced during the following class period. Then, blank tiles (previously covered on white primer) and proper materials (brushes and paints) were provided to produce a couple of tiles. The last step was a presentation of the final products.

Each specific step carries its own set of skills to be developed as follows: brainstorming as the first step was intended as a way to both promote creative thinking and allow students to prompt vocabulary and knowledge related to the topic. As it involves the interactions amongst the students and with the instructor, interpersonal skills came to place. The exchange of information implicates give-and-take concepts and experiences that build knowledge. Brazilian philosopher-educator Paulo Freire (2000) points out the importance of such interactions where all those involved contribute to the process of teaching and learning. It is within the dynamics of this process that knowledge is built and shared; otherwise, to think that there is one of the parts as the sole source of knowledge and another as the repository of its content means to reduce education and the learning process to a content-based transference. By exchanging information from various sources of experiences, learning becomes more meaningful. Freire (1981) also states that while reading words, learners bring their own experiences from their world to the process of deciphering letters, words, and producing meaning. Incorporating students' previous experiences on the semantics related to the 
word tile, and more specifically Portuguese tiles values learning experiences through a constant interaction and negotiation of meaning. It is a constructive process.

By incorporating authentic materials, the second step consisted of reading the introduction of a book published by various Portuguese researchers on the traditions of tiles in Portugal for over four centuries. The book also presents enhanced quality pictures of forty different sites throughout the country exemplifying tile masterpieces considered Portuguese wonders, from $17^{\text {th }}$ century to nowadays, accompanied by the analysis written by recognized Portuguese researchers. Students had the opportunity to look at some of those sample pictures and their respective analysis. Such an activity required the use and comprehension of some lexicon related to the field and history of different techniques and patterns carried throughout the centuries of tile production. The access to pictures was a significant aspect of this learning experience because it visually fed students' expectations about colors and lines, figures, and shapes of tiles. Later on, they would be producing their own tiles using those pictures as references to their own production. As the interpretational skill came about in the reading activity, students also, as part of this second step, answered a questionnaire based on the reading. That required some research in the dictionary and also a consultation with the chronology of the tile production in Portugal that accompanies the introduction they have previously read.

The following step consisted of participating in a live-cam presentation on ceramics and Portuguese tiles lead by a Brazilian ceramist. He presented his studio where his classes in ceramics are taught in Brasilia, Brazil, introduced some tools, materials, and techniques used in the process of creating art pieces on ceramics. This interpersonal-skill oriented activity also included a questions and answers (Q\&A) moment, so students could interact more directly with the instructor/ artist. As a follow up, during next class, participants talked about the experience and evaluated the pros and cons of the interaction. It is relevant to mention the use of technology associated with this step generated a good sense of connection with the Lusophone diaspora in a cross-cultural experience for all those involved.

In the sequence, hands-on activity was to have students create on paper the draft of their intended design for a couple of tiles. At this point, the book with samples was available as well as Internet search for colors, lines, geometric figures, etc. It was imperative that students used Portuguese vocabulary only - during these non-structured instructional moments one can notice the incorporated use of the lexicon and new structures acquired as each step was taken. Students could use pencil colors to reproduce also the colors of the tiles as a sample. After that, they were handed some special plastic squares that would become their stencil to paint over the tile. One of the students asked if it would be possible to freehand paint the tile - which was an acceptable option. Since each student had the possibility to paint two tiles, the instructor suggested they painted one as a traditional Portuguese tile and the other was produced as their own choice of design, as many samples that were presented in class. A great moment and outcome was having the chance to observe students making their own decisions on how their final product should look like. Experimenting the possibilities of shapes, colors, designs, and all the aspects of the tiles empower them to own their aesthetical choices and preferences, which can reflect on and be carried to many aspects 
of their lives. Some of them had never produced stencils to paint over, thus some of them tossed their drawing because they were too elaborate to be hand produced on stencil.

When students were informed that they would be painting tiles, previously to the beginning of their work, a sentence was used by one of the students several times. The sentence was: "I feel like a kid working with arts and crafts again. I can't remember the last time I did that in my classroom". At first, the comment sounds like it was a promise to be some kind of stress-relief, loose, and fun type of activity. By starting on each step towards the culminating activity of painting itself, one could notice that his comment tended to become more of aware of the commitment to a learning activity as a process geared to achieve a goal. One could still note that his tone resonated cheerfulness - which has everything to do with the process of learning. Thus, the materials to produce tiles were provided.

This was a significant part of the work because it was a moment when students would produce an art object as a translation of the information they had been working with. What mattered, more than the final object produced, was to become aware of how much had been exchanged (as far as information goes) among the participants of the process and through many different means of communication. The timeframe of a fifty-minute class was obviously not enough to complete the painting - which is understandable and even expected. The excitement about this step did not disappoint anyone in the classroom. From moments of silence and concentration to sequences of intense dialogue and compliments on each other's jobs is always a rewarding moment for those who have the privilege to participate in an authentic process of teaching and learning. Another 50-minute class period was necessary to finish designing the tiles.

One following step was the presentation of the final product, when all could describe the aspects selected to represent their idea of a Portuguese-like tile: colors, shapes, figures, motifs, etc. As each participant led their own script, the moment created the opportunity to practice and develop presentational skills, a crowning moment of the communication proficiency when the negotiation of meaning involves not only the corollary of acquired lexicon but also the maturity level of the language in which the speaker can assess the audience, select adequate vocabulary, perform non-verbal skills, and deliver confidence. During the second half time of the class, instructor and learners assessed the project. Suggestions were many. Feedback was very positive.

\section{Discussion}

The students were asked if, how, and when they learned or heard about Portuguese tiles. The objective of unfolding this question was to explore patterns. Indeed, when participants define tiles as ceramic paintings (pequenas pinturas em ceramicas), the synonym shows a cultural matrix. The vast majority had minimum to some knowledge about decorated tiles on venue flooring and walls gathered from the Internet. When they shared that they did not have information about the tiles history, origin, and creation, students were reinforcing the academic debate that practice is perceived as a social interaction, dynamics, or behavior, e.g. seeing these tiles on the wall of small Portuguese store during local church food festival:

Eu ouvi falar dos azulejos alguns anos atrás, no festival de comida da minha igreja, havia uma pequena loja de comida portuguesa decorada com os azulejos. 
Perspectives, on the other hand, are demonstrated as values, philosophical beliefs, and assumptions. Clearly, practice and perspectives are fluid and at times interchangeable because attitudes are always influenced by life repertoire. In such example, the practice-perspectives overlap is in the inclusion of the information that the student learned about Portuguese tiles at a local church food festival.

Considering that practice and perspectives comprehend intangible values, meanings, and metaphors of a given culture, the interpretation of the participants' feedback demonstrated that culture learning, whether it occurs in a foreign language or second language context, inside or outside the classroom, with or without teachers, through books or through people, is best seen as a lived experience, as a personal encounter with another way of life. The transcultural reference to heritage is noticed with the comparison to Mexican and their grandparents' tiled houses also pertain perspectives as these data underlie the cultural practices and products of a society.

Finally, the production of their tiles as the final goal is literally what PBL Works suggests as public cultural product at Buck Institute for Education, in the sense there might be an art exhibition (yet to be confirmed) to a diverse audience and beyond classroom to reinforce global competence capacity building. Products can reflect one or more perspectives and represent practices interaction (home and target culture).

\section{CONCluding Remarks}

The immediate feedback chat evolved around three vertical themes: project experience, informative load, and cultural reference. These codes emerged purely from the questions to serve as umbrella coding. Then, from these major categories, the respondents provided with the core phenomenon as horizontal axial coding. These axial codes were pulled out from the interview data to establish patterns and correspondence between umbrellas and axes.

The conversation was held in Portuguese and it was question-oriented. At this point, it is important to reinforce that the answers are not mutually exclusive, meaning the sum of the percentages may exceed one hundred percent because the respondents are given the opportunity to agree with the previous participant, and still elaborate on their answers, for instance.

The participants (instructor and students) were recorded, and their identities were kept anonymous, as demanded for research rigor by the Family Educational Rights and Privacy Act 20 U.S.C. $\int 1232 \mathrm{~g}$; 34 CFR Part 99 (FERPA), the federal law for privacy protection in collegiate related issues. For so, each participant was given a reference number as a fictitious name. As the participants answered the questions in the target language, the verbatim transcription showed words, phrases, and/or sentences in Spanish. This overview reveals that even though the use of Spanish draws an elucidating parallel here sibling languages interference falls beyond the scope of this study (CLEMENTS, 2003; DE SOUZA, LYSTRUP \& SCHARFF, 2006). Further reading is suggested of the resourceful literature about language interface, sentence parsing and related themes as an implication (CHILD, 2013; ROTHMAN, 2009).

When asked their opinions about the presentation, the explanation, and the class they had about the tiles, around sixty-five percent considered the project interesting because they could learn from such an experience. Thirty percent stated that they had access to behind the scenes and the background. 
Interestingly, all respondents referred to the occupation to answer the question about the information they were exposed to: professional (profissional), the specific place to refer to an art studio (lugar especifico), and expertise (prática e ler livros sobre azulejos). This goes along with PBL theoretical tenet of discovering themes one is particularly interested in.

In regard to the question about cultural reference, thirty five percent found the fact that both Portugal and Mexico have white and blue tiles culturally relatable. Last but not least, when Portuguese tiles are compared with Mexican ones, one recognizes Latino representation embodiment in U.S. class settings.

\section{REFERENCES}

ACTFL Proficiency Guidelines. American Council on the Teaching of Foreign Languages, 2012. Disponível em http://bit.ly/38hl6Bm. Acesso em 23/11/2018.

ALMEIDA, C. Portuguese Immigrants: the centennial story of the Portuguese Union of the State of California. [s.l.]: Supreme Council of União Portuguesa do Estado da Califórnia (U.P.E.C.), 1992. Disponível em http://bit.ly/2NJbjMS. Acesso em 20/09/2019.

BIRD, M. S. Products, practices, and perspectives in the World Language classroom: a unit on Mexican food for a high school Spanish 1 class. Dissertação de Mestrado. Departamento de Espanhol e Português. Brigham Young University, Provo, 2014.

BRANDL, $\mathrm{K}$. The integration of internet-based reading materials into the foreign language curriculum: from teacher- to student-centered approaches. In: Language Learning \& Technology. University of Hawai $i$ at Mānoa, v. 6, n. 3, 2002, p. 87-107.

BRITO, E. Grammatical gender in the interlanguage of English-speaking learners of Portuguese defense language institute. In: Portuguese Language Journal, v. 9, n. 7, 2015, p. 1-21.

CALIFORNIA LANGUAGE TEACHERS' ASSOCIATION (CLTA, 2019). SB 5 Karnett Bill of 2005. California World Language content standards for public schools k-12. Disponível em http://bit. ly/38nQcY2. Acesso em 18/02/2019.

CARLA Professional Development. Center for Advanced Research on Language Acquisition. Research and Programs. University of Minnesota. December 2017. Disponível em http://bit.ly/30z32jL. Acesso em 18/02/2019.

CHILD, M. W. language learning perceptions: the role of Spanish in 13 portuguese acquisition. In: Portuguese Language Journal, v. 7, 2013, p. 1-55.

CLEMENTS, J. C. On classifying language-contact varieties. In: Selected Proceedings of the First Workshop on Spanish Sociolinguistics. Somerville, MA: Cascadilla, 2003, p. 1-10.

COENTRO, S. Estudo da camada pictórica na azulejaria portuguesa do século XVII. Dissertação de Mestrado em Conservação e Restauro, Área de especialização: Cerâmica e Vidro da Faculdade de Ciências e Tecnologia da Universidade Nova de Lisboa, Portugal, 2010.

CONDLIFFE, B.; QUINT, J.; VISHER, M. G.; BANGSER, M. R.; DROHOJOWSKA, S.; SACO, L. \& NELSON, E. Project-based learning: a literature review. New York, NY: MDRC, 2017, p. 1-84.

DE SOUZA, I.; LYSTRUP, R. \& SCHARFF, L. Linguistic sibling rivalry: mutual interference between Portuguese and Spanish. In: Portuguese Language Journal, v. 10, n. 2, 2006.

DEWEY, J. The future of liberalism. In: The Journal of Philosophy. London and New York: Routledge, v. 32, n. 9, 1935, p. 225-230.

KILPATRICK, W. H. A reconstructed theory of the educative process. In: Teachers College Bureau of Publications, New York: Columbia University, 1937.

DOOLY, M. \& RANDALL, S. Becoming little scientists: Technologically-enhanced project-based language learning. In: Language Learning \& Technology. University of Hawaíi at Mānoa, v. 20, n. 1, 2016, p. 54-78. 
DUNCAN, G. \& MET, M. STARTALK: From paper to practice. College Park, MD: National Foreign Language Centre at the University of Maryland, 2010.

FRAGA, S. F. A azulejaria portuguesa como patrimônio em Porto Alegre: vestígios do passado. Monografia de bacharelado na Faculdade de Biblioteconomia e Comunicação da Universidade Federal do Rio Grande do Sul, Porto Alegre, RJ, 2018.

FRAGOULIS, I. \& IAKOVOS, T. Project-based learning in the teaching of English as a foreign language in Greek primary schools: From Theory to Practice. In: English Language Teaching, v. 2, n. 3, 2009, p. 113119.

FREIRE, P. A importância do ato de ler: em três artigos que se completam. São Paulo: Autores Associados: Cortez, 1981.

FREIRE, P. Pedagogia da autonomia: saberes necessários à prática educativa. São Paulo: Terra, 2000.

FREY, K. The project method. Thessaloniki: Kiriakidis Brothers' Publishing House, 1986.

GRABE, W. \& STOLLER, F. L. Teaching vocabulary for reading success. In: The TESOL Encyclopedia of English Language Teaching, 2018, p. 1-7.

GUIMARÃES, E. Texto, discurso e ensino. São Paulo: Contexto, 2019.

KATRADIS, M.; FOX, R. K. \& TIAN, J. Learning to implement the five cs by living the five cs: portfolios and reflection in an international teacher professional development program. In: NECTFL Review, v. 80, 2017, p. 45-78.

KINGSTON, S. Project based learning \& student achievement: what does the research tell us? In: PBL Evidence Matters, Buck Institute for Education, Novato, CA: PBL Works, v. 1, n. 1, 2018.

LEIVA MATUS, A. Can teachers influence in their students' motivational and anxiety levels through the use of certain teacher strategies, so that students are able to produce more oral communication in EFL classes? Dissertação de Doutorado, Faculdade de Educação da Universidad Alberto Hurtado, 2018.

LUNDGAARD, G. \& SAUER, T. STARTALK community: developing world language teachers through principles and practice. In: The Language Educator, Alexandria, v. 13, n. 3, 2018, p. 48-52.

MERGENDOLLER, J. R. What can we learn from John Hattie about project-based learning? Novato, CA: PBL Works, 2016.

NATIONAL STANDARDS COLLABORATIVE BOARD. World-Readiness Standards for Learning Languages. American Council on the Teaching of Foreign Languages, 2015. Disponível em http://bit. ly/2sCExWb. Acesso em 19/02/2018.

OMAGGIO-HADLEY, A. \& TERRY, R. Teaching language in context. Boston: Heinle \& Heinle, 2001.

OSBORNE, D. Cinematographic resources as meaningful affordances in a foreign language class. Views from Below: The Underdog in Contemporary Latin American and Spanish Film. 2017. Disponível em http://bit.ly/2R5ztD8. Acesso em 23/09/2019.

PAIS, A. N.; ALMEIDA, A. [et a]. Azulejos: maravilhas de Portugal. V.N. Famalicão: Centro Atlântico Ltda., 2017.

ROTHMAN, J. Understanding the nature and outcomes of early bilingualism: romance languages as heritage languages. In: International Journal of Bilingualism, v. 13, n. 2, 2009, p. 155-163.

SAAVEDRA, A.; RAPAPORT, A.; MARWAH, E.; CARLE, J.; LIU, Y.; JOHNSON, S. J.; LI, J.; HOEPFNER, D.; GARLAND, M. Shifting to project-based learning in the Advanced Placement context. Novato, CA: PBL Works, 2019.

SHRUM, J. L. \& GLISAN, E. W. Teacher's handbook: contextualized language instruction. Boston: Heinle and Heinle, 2010.

STOLLER, F. Project work: a means to promote language and content. In: Jack, C. R. \& Willy, A. R. (Eds.). Methodology in Language Teaching: An Anthology of Current Practice, p. 107-120, Cambridge: Cambridge University Press, 2002.

STOLLER, F. Establishing a theoretical foundation for project-based learning in second and foreign language 
contexts. In: BECKETT, G., H. \& MILLER, P. C. (Eds.). Project-Based Second and Foreign Language education: past, present, and future (p. 19-40). Greenwich, Connecticut: Information Age Publishing, 2006. SILBERMAN, M. L. The handbook of experiential learning. San Francisco: Pfeiffer, 2007.

THOMÉ-WILLIAMS, A. C. Developing intercultural communicative competence in Portuguese through Skype and Facebook. In: Intercultural Communication Studies, v. 25, n. 1, 2016.

TROYAN, F. J. Standards for foreign language learning: defining the constructs and researching learner outcomes. In: Foreign Language Annals, v. 45, n. 1, 2012, s118-s140.

YOUNG, D. J. The standards definition of culture and culture instruction in beginning and intermediate Spanish textbooks. In: Northeast Conference Review, v. 45, 1999, p. 17-22. 